Journal of medical \& pharmaceutical Sciences

Volume (4), Issue (3) : 30 Sep 2020

$P: 41-55$
AJSRP

ISSN: 2522-333X
مجلة العلوم الطبية والصيدلانية

المجلد (4)، العدد (3) : 30 سبتمبر 2020 م

ص: 41 - 55

\title{
The extent of the ability and readiness of hospitals in Amran Directorate in Yemen to face and prevent outbreaks of Coronavirus disease (COVID-19) - A field study
}

\author{
Mohammed Ali Qatinah \\ Rehab Qayed Al- Omari \\ Nouria Saleh Al- Hajli \\ Amal Abed Al- Bajal
}

National Community Collage || Amran || Yemen

\begin{abstract}
The World Health Organization has classified the Coronavirus as a global pandemic (cataclysm), and thus an outbreak of this epidemic that has struck the world's largest economies will be disastrous in Yemen.

The purpose of the study: The current study aims to measure the ability and readiness of Amran Directorate hospitals and its employees to face and prevent outbreaks of Coronavirus (COVID-19). Research methodology: A descriptive study was conducted between January and May 2020, with a sample of 227 people from the health team and administrators in Amran Directorate hospitals. The study collected data by using a questionnaire that consisting of two parts: a part of the data relating to the demographic properties, the second part of the collection of data related to the measure of the readiness. Main results: In terms of the availability of testing tools and solutions, they are not available in Amran Directorate hospitals $(94.7 \%)(94.3 \%)$, and there is a large shortage of remote temperature measuring devices(74.4\%) , respirators (85.5\%), and the number of beds(83.7\%) in hospitals. Recommendations: The study recommends that there is a need to equip Amran Directorate hospitals and provide them with all the devices, equipment, tools and special requirements to confront the Coronavirus and prevent the spread, as well as work on training and rehabilitation of their workers to deal with infected and suspected of being infected with the Coronavirus.
\end{abstract}

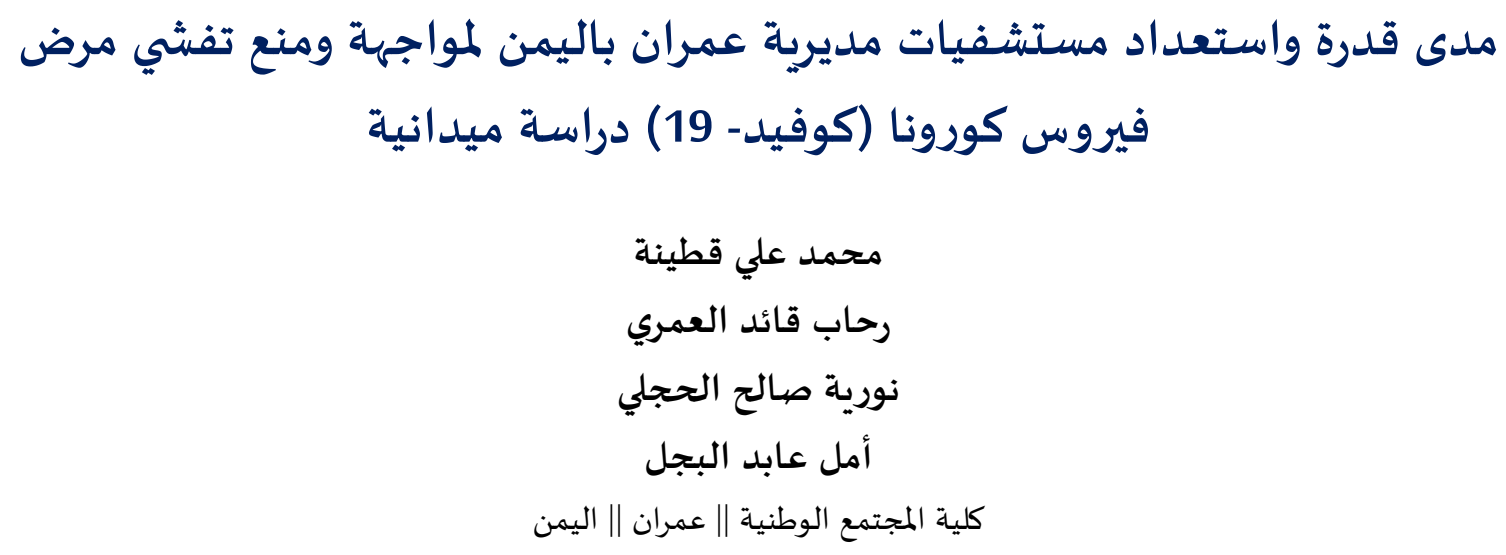




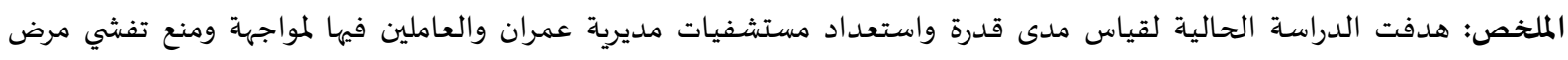
فيروس كورونا (COVID-19). واستخدم الباحثون منهجية البحث الوصفي المستي؛ باستخدام استبانة تم توزيعها بين يناير ومايو المايو

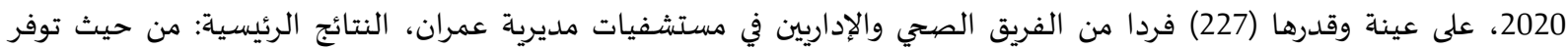

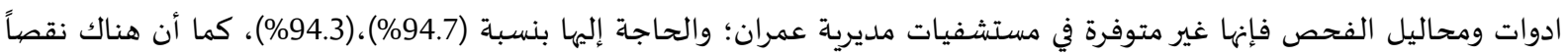

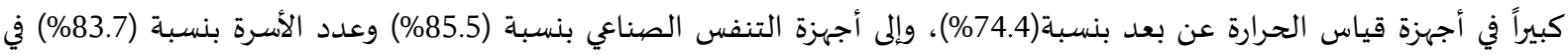

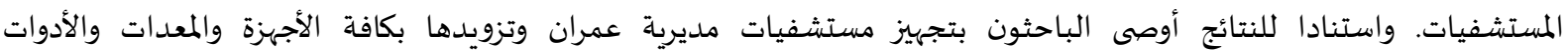

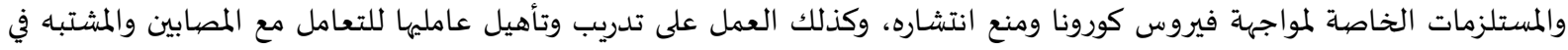
اصابتهم بفيروس كورونا. الكلمات المفتاحية: فيروس كورونا، مستشفيات مديرية عمران، استعداد المستشفيات.

المقدمة Introduction

يعد فيروس كورونا المستجد لعام 2019 سلالة جديدة من الفيروسات التاجية التي تم الابلاغ عنها لأول مرة في 31 ديسمبر 2019، وذلك بعد تصنيف منظمة الصحة العالمية فيروس كورونا بالوباء العالي "جائحة"، علت العديد من الأصوات المحذرة أنه من بعد تفشي الوباء في الصين وأوروبا، من المتوقع انتشار الوباء في البلدان التي تعاني من نظم صحية هشة وأزمات إنسانية ونزاعات (Kaamil, 2020).

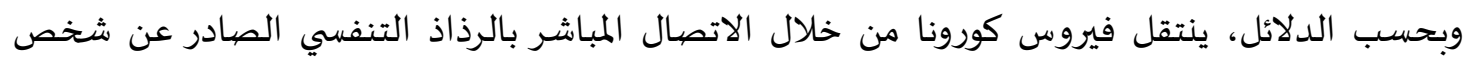

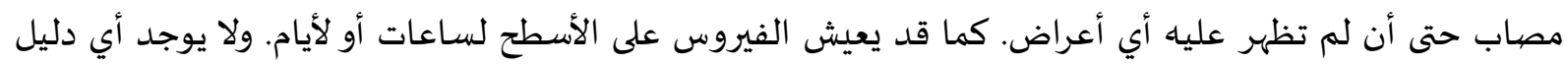

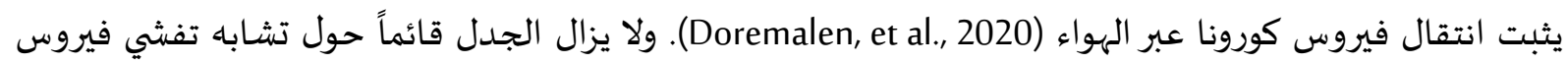

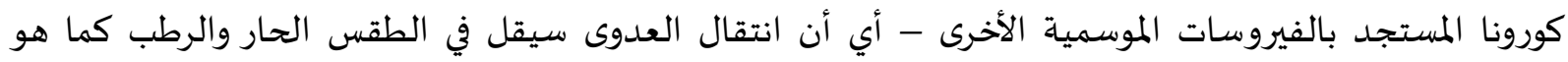

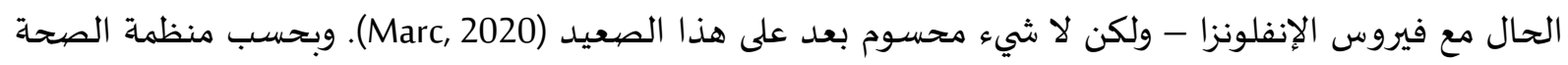

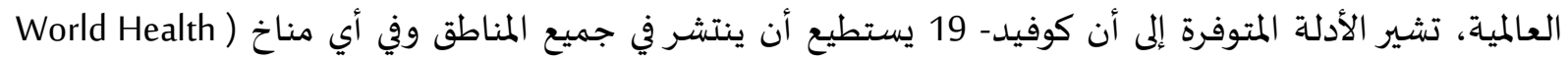

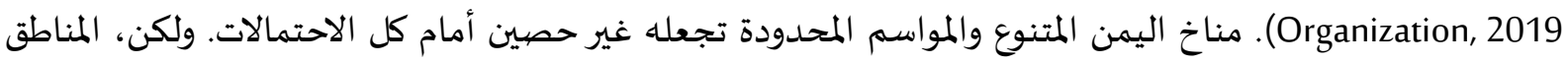

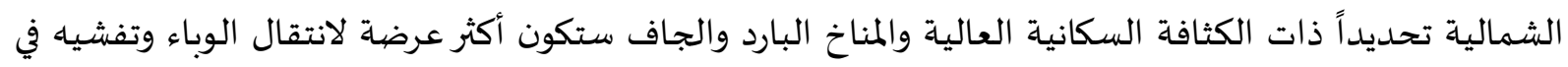
الطقس البارد.

يدخل اليمن عامه السادس من الصراع والذي نتج عنة أزمة إنسانية كبرى ونظام صبح هش (UN Office) for the Coordination of Humanitarian Affairs, 2019 العالم، سيكون في اليمن كارثي. تشمل العوامل التي من شأنها أن تساعد في تفشي الوباء: ضعف النظام الصيحي

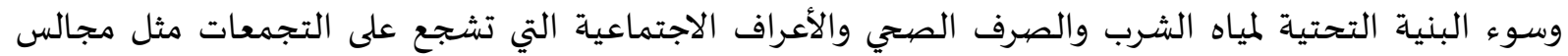
مضغ القات.

وما ينذر بالخطر ويعتبر مقلقاً هو افتقار العاملين في مجال الرعاية الصحية في اليمن إلى التدريب اللازم والحماية المطلوبة من كوفيد- 19ولذلك يجب اتخاذ تدابير عاجلة لا سيما على مستوى التأهب وتوفير التدريب الكافي

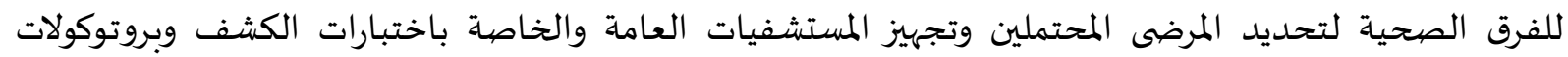

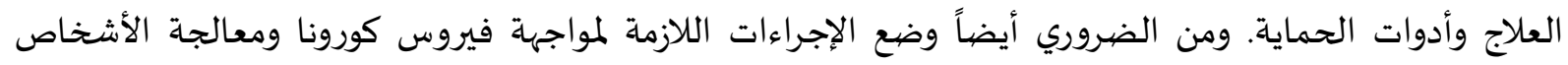
المصابين في حال انتشر فيروس كورونا في اليمن (IFRC, UNICEF \& WHO,2019). 
تتمثل مشكلة الدراسة في التساؤل الرئيسي التالي:

- ما مدى قدرة واستعداد مستشفيات مديرية عمران والعاملين فيها لمواجهة ومنع انتشار فيروس كورونا؟

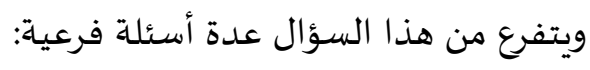

1. هل هناك ما يكفي من معدات الفحص، والملابس الوقائية والأقنعة، وأجهزة التنفس الصناعي، والأسرة في

$$
\text { المستشفيات؟ هل هنات }
$$

2. هل اتخذت إدارة المستشفيات الإجراءات الاحترازية والوقائية لتأمين العاملين فهها؟

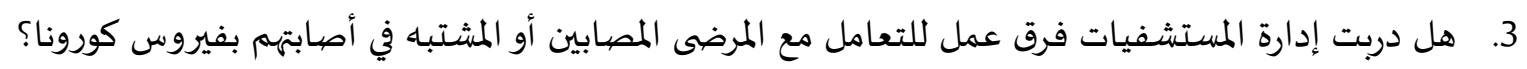

\section{فرضيات البحث:}

1. لا توجد فروق معنوية في تقديرات أفراد عينة الدراسة لمدى قدرة واستعداد مستشفيات مديرية عمران تعزى

لمتغير التخصص والمؤهل العلمي والخبرة والفئة العمرياة عند معامل فرق معنوي (p.value=0.05).

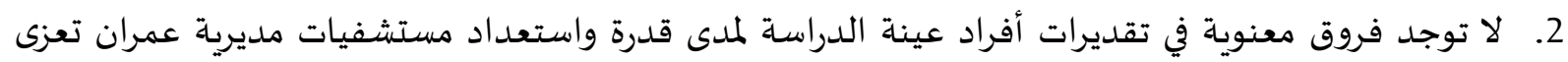
لمتغير الجنس ونوع المستشفى عند معامل فرق معنوي (p.value=0.05).

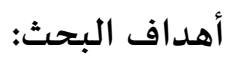

تهدف هذه الدراسة إلى قياس مدى تأهيل واستعداد مستشفيات مديرية عمران والعاملين فيها لمواجهة ومنع

انتشار فيروس كورونا (Covid-19).

$$
\text { ويتفرع من هذا الهدف الأهداف الفرعية الآتية: }
$$

1. بيان مدى الحاجة لمعدات الفحص، والملابس الوقائية والأقنعة، وأجهزة التنفس الصناعي، والأسرة في

$$
\text { مستشفيات مديرية عمران. }
$$

2. 3. التعرف على دور إدارة المستشفيات في تدريب فرق عمل للتعامل مع المرضى المصابين أو المشتبها في أصابتهم

بفيروس كورونا.

أهمية البحث:

1. تنبع أهمية البحث من أهمية وخطورة انتشار مرض فيروس كورونا في الوقت الحالي حيث أن الانظار تتجهاه

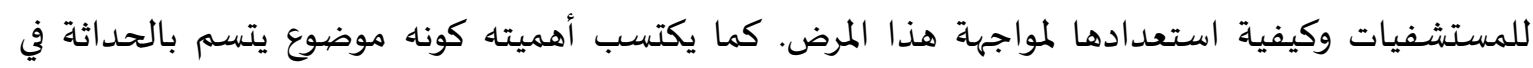

$$
\text { المجتمعات العالمية. }
$$

2. يتوقع الباحثون أن تشكل هذه الدراسة إسهاما علميا حيث إنها تقدم دليلا على قياس مستوى استعدادات

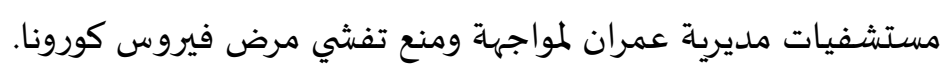

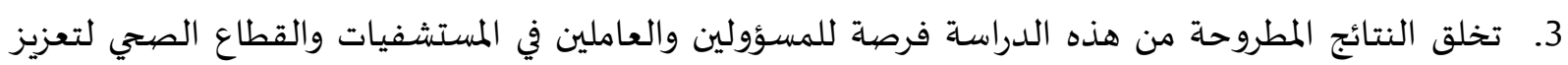

$$
\text { الاستعدادات لمواجهة ومنع تفشي مرض فيروس كورونا في مديرية عمران. }
$$

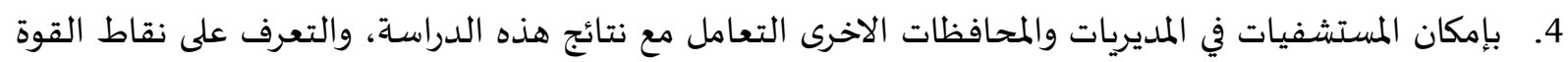

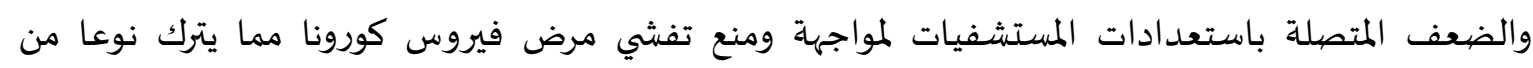

$$
\text { الاستفادة وتقليص الاثار السلبية بما يحقق المنفعة العامة. }
$$


2- 2 - 2 الإطار النظري والدراسـات السـابقة

أولاً الإطار النظري

\section{الفيروسات التاجية (فيروسات كورونا) Coronaviruses:}

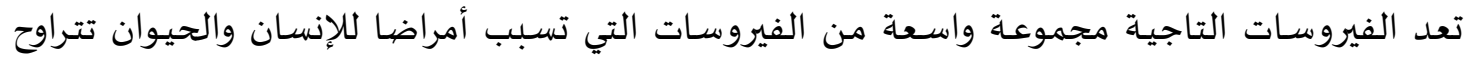

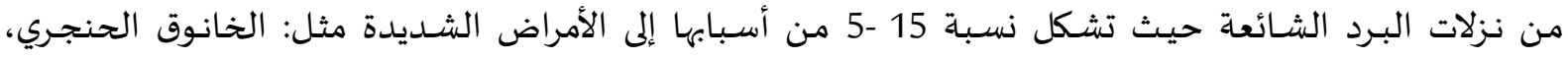

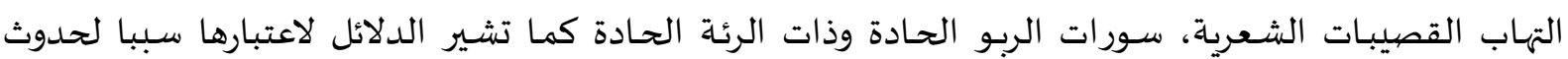

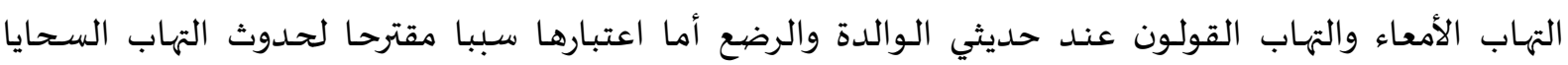

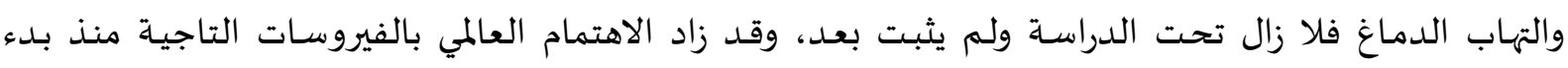

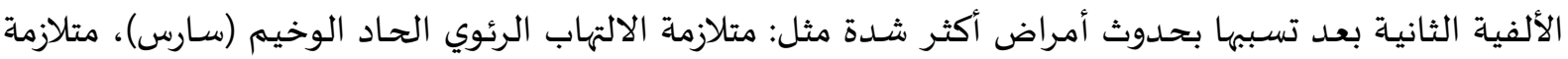
الشرق الوسط التنفسية (ميرس) وحاليا مرض الفيروس التاجي 2019(كوفيد- 19 أو COVID -19)الذي تسبـيبه سلالة جديدة من الفيروسات التاجية لم يسبق اكتشافها لدى الإنسان النسان.

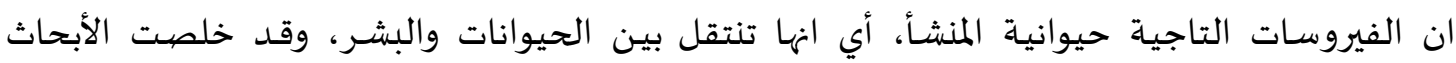

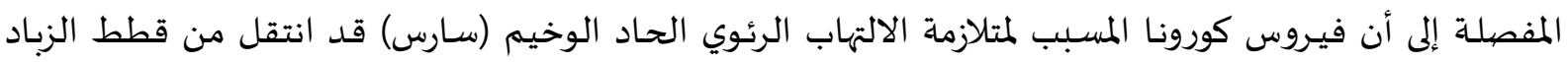

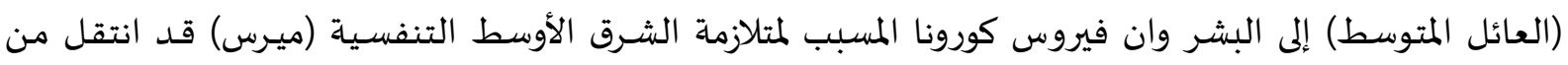

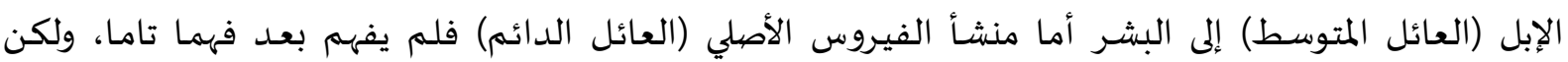

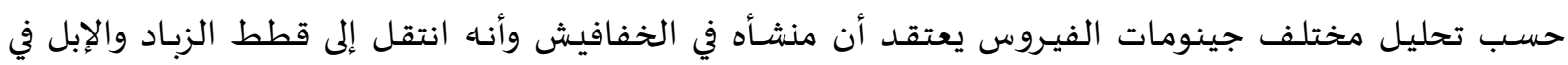

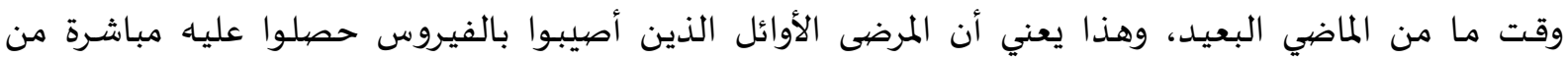

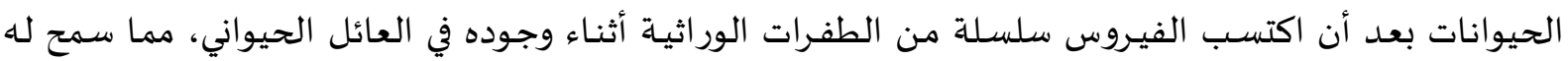

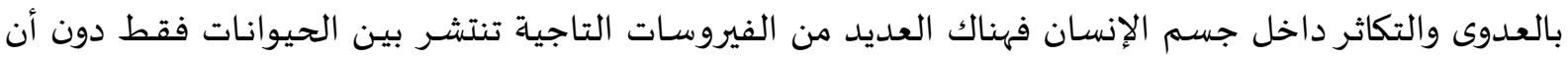

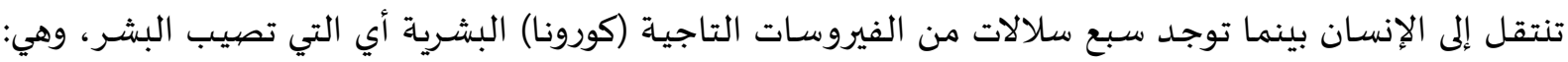

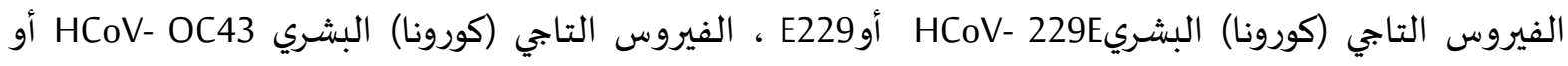

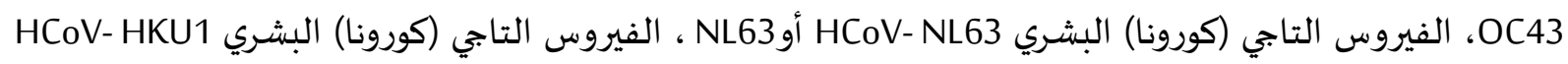

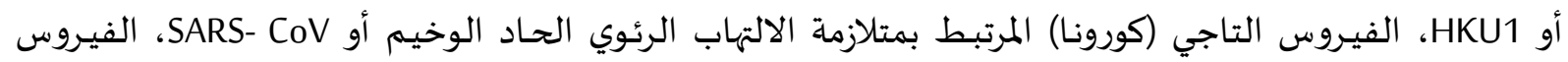

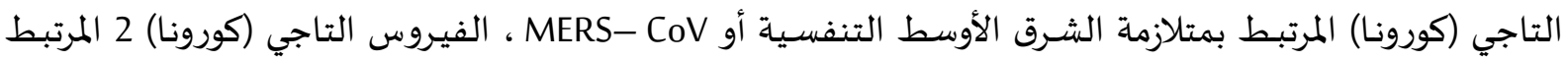

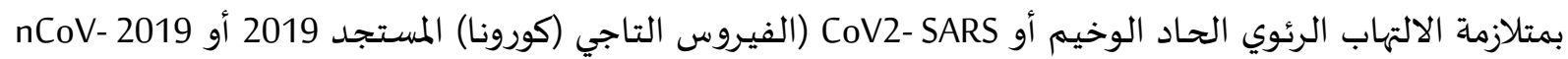

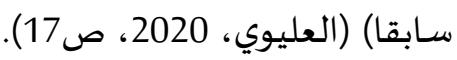
كما عرفت منظمة الصحة العالمية فيروس كورونا المستجد: بانة زمرة واسعة من الفيروسات يمكن أن

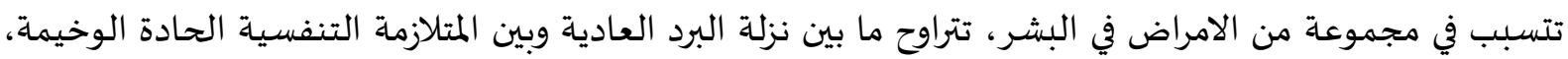
ولا يوجد حاليا دواء محدد للوقاية منه. (منظمة الصحة العالمية، 2020).

مواجهة الأطقم الطبية للأوبئة والجوائح مثل (فيروس كورونا المستجد):

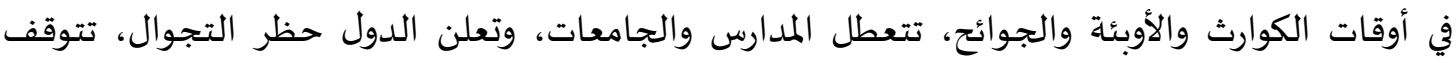

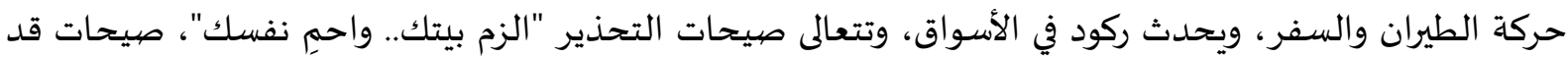


تصلح مع البعض ولكنها لا تصلح للعاملين في القطاع الصجي من أطباء وممرضين وعمال وإداريين يجدون أنفسهم في الصفوف الأولى "على خط النار".

وتُعَد العدوى التي قدل يتعرض لها الأطباء والعاملون في القطاع الصحي من القضايا الصحية المهمة والتي

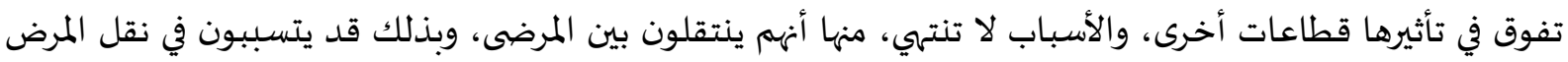

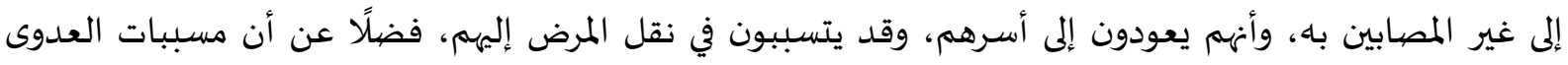

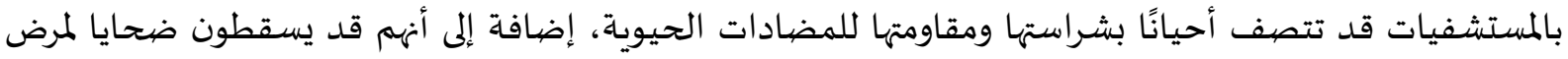

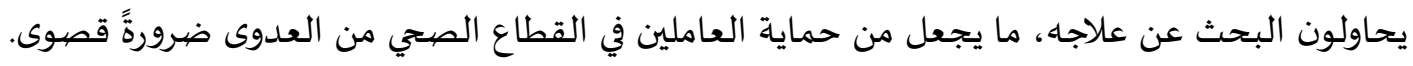

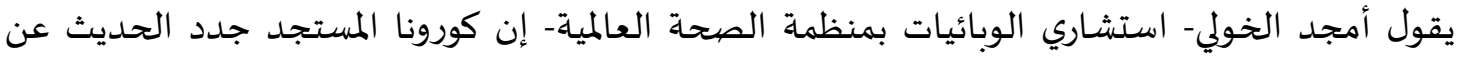

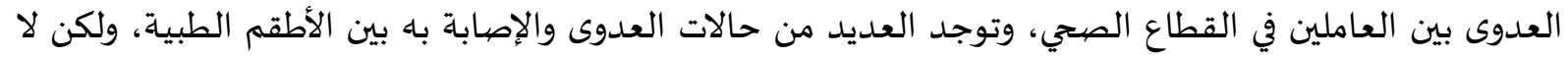

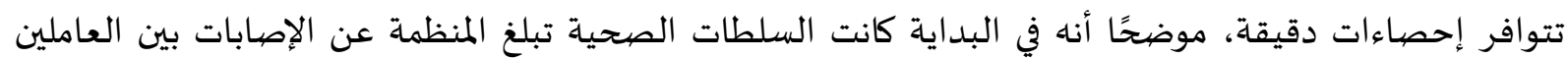
بالقطاع، ولكن مع انتشار الوباء لم يتم تحديث البيانات. وحول ما إذا كان العاملون في مستشفيات العزل يحتاجون إلى إجراءات إضافية لحماء لحمايتهم من العدوى،

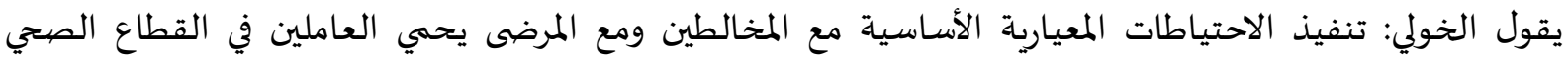

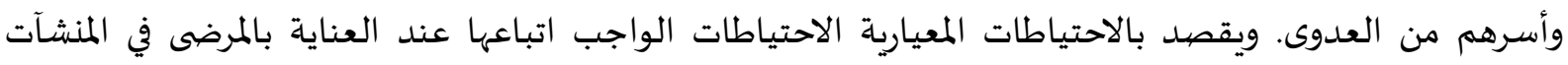

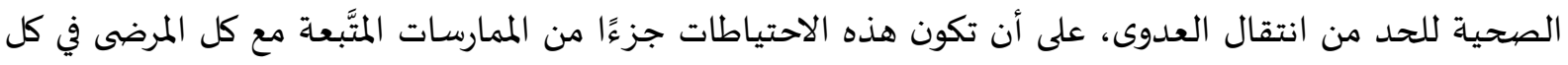

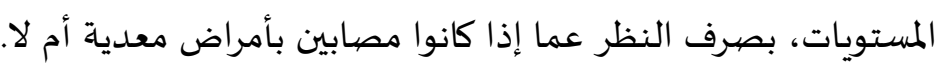

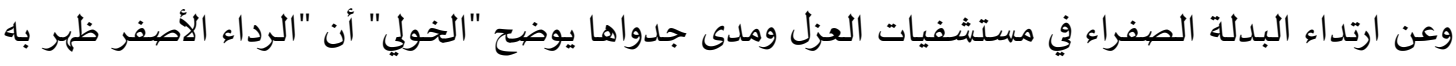

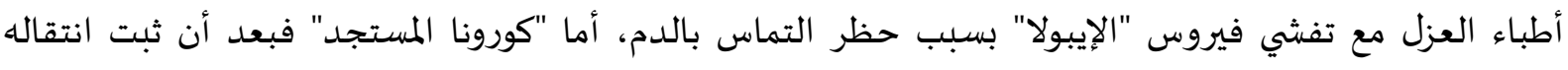

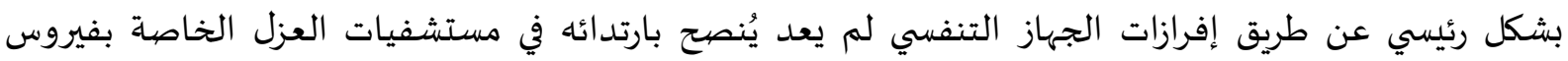

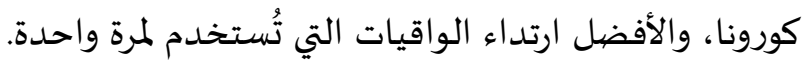
وهناك نصائح نشرتها منظمة الصحة العالمية للعاملين في القطاع الصحي بغية الاعتئناء الصاء بصحتهم، منها

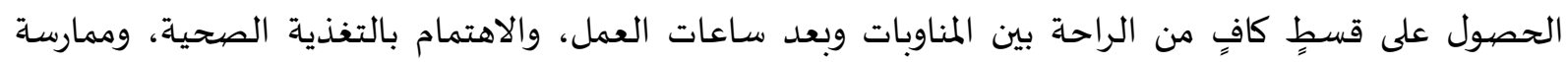

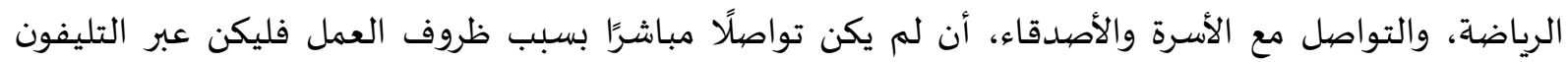
ومنصات السوشيال ميديا (طنطاوي، 2020).

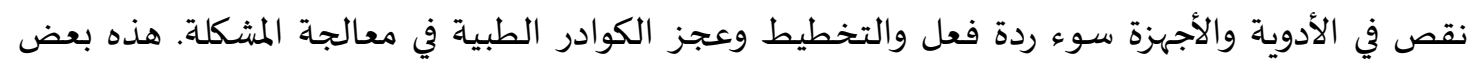

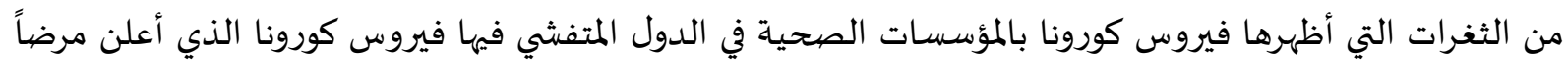

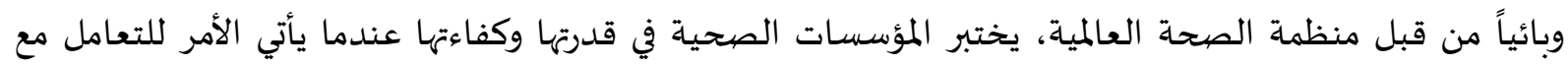

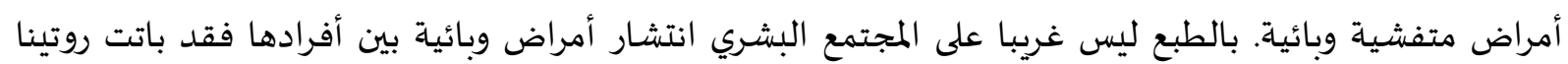

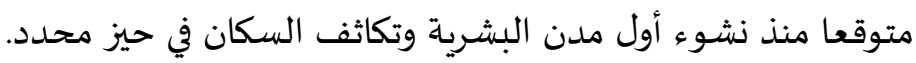

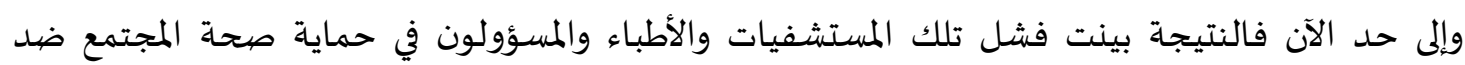

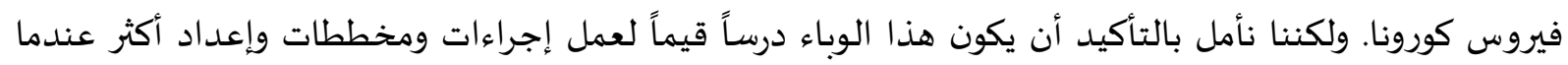
يأتي الأمر للأمراض المعدية الأخرى؛ حيث لم تجد محاولة المختبرات الطبية في اكتشاف لقاح للفيروس ولم تفد المضادات الحيوية التي كانت تقتل البكيتريا بشكل فعال جداً ضد الفيروس. لجأت المعيك حينها المستشفيات إلى اتخاذ 
إجراءات وقائية واحترازية بدلاً من العلاجية وهذا يعني حجر الشخص وعزله عن الآخرين ولكن سرعان ما اكتشف

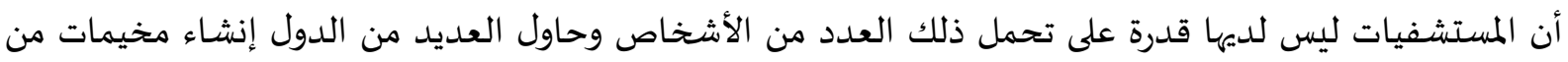

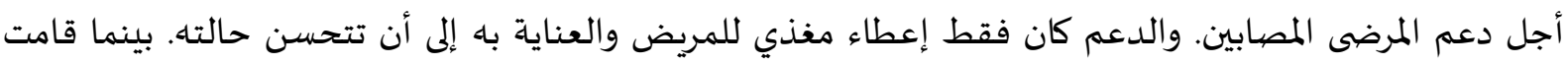

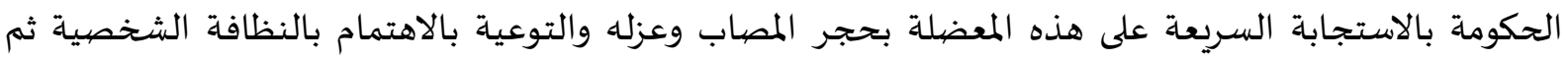
الأهم منها القيام بحظر التجوال وغلق الأماكن العامة.

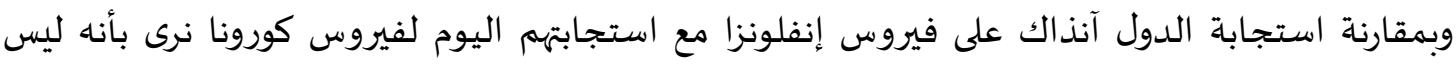

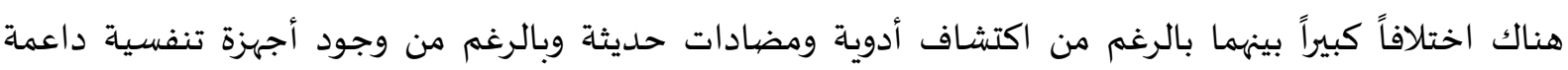

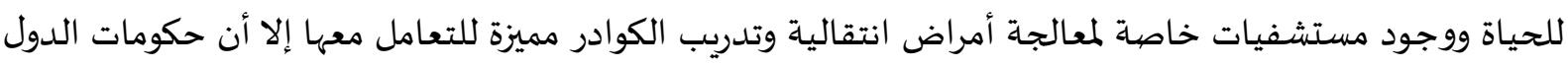

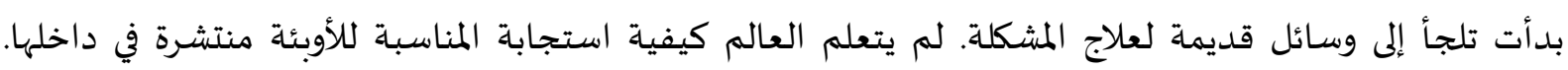

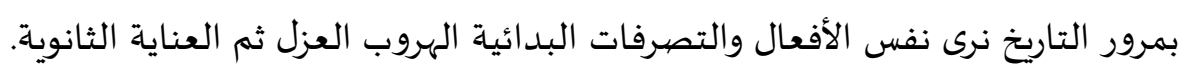
هناك اليوم مصادر مادية كافية ومعلومات علمية وافية للوقاية من والاستجابة فعالة للأمراض الوبائية.

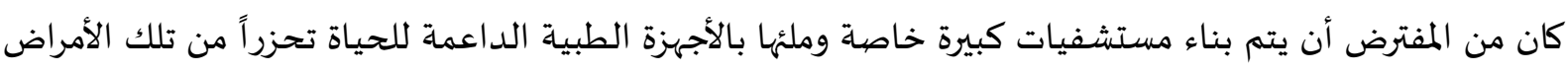

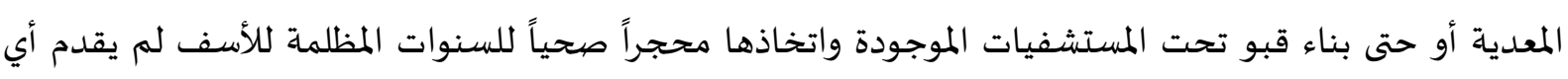

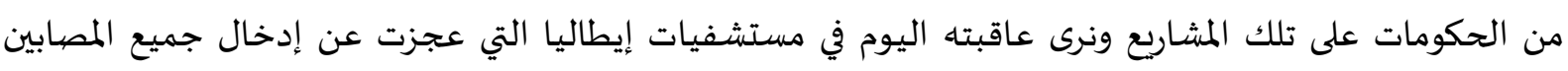

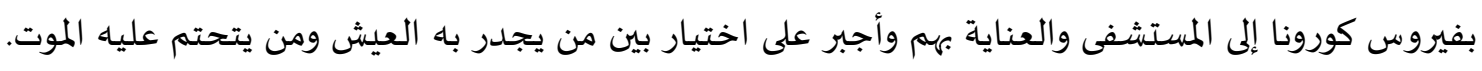

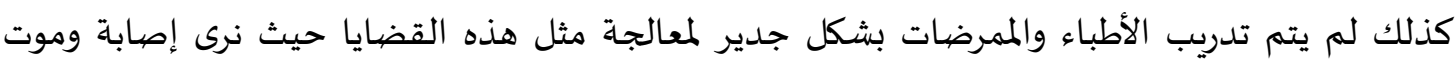

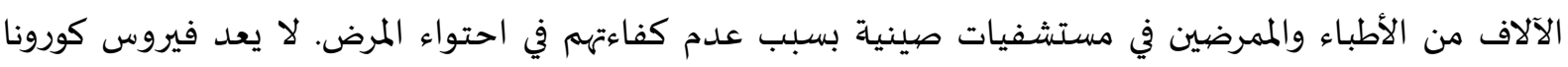

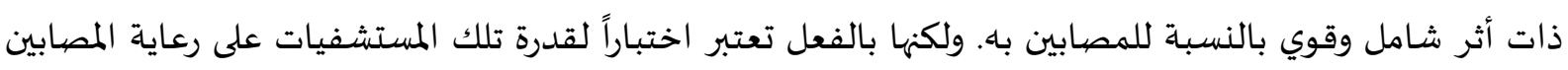

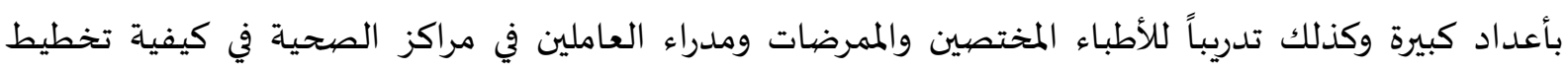

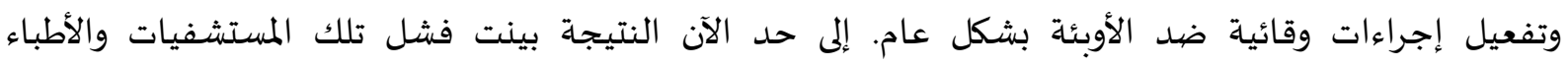

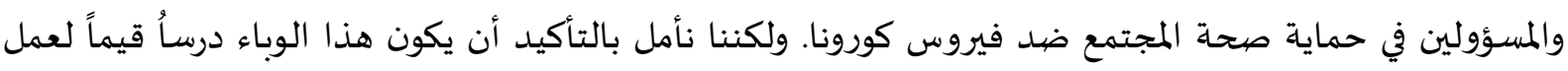

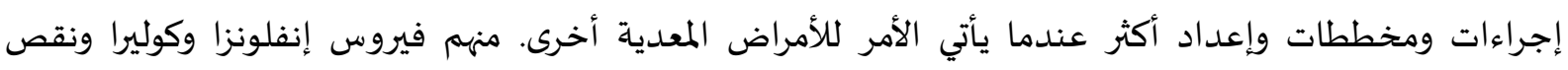

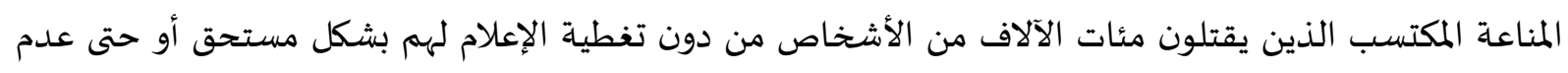

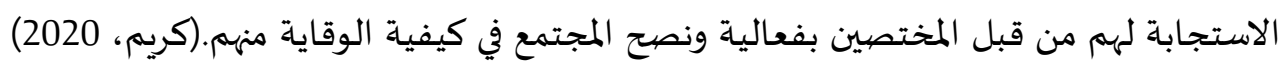

$$
\text { ثانياً- الدراسـات السابقة: }
$$
- دراسة (السعودي، 2020) هدفت الدراسة للتعرف على طبيعة وجود فيروس كورونا وطرق انتشاره وسبل

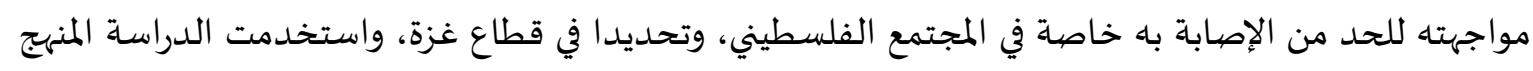

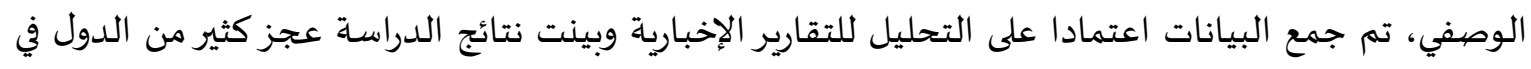

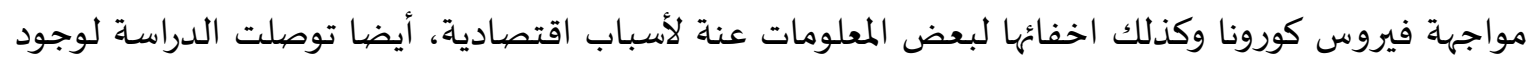

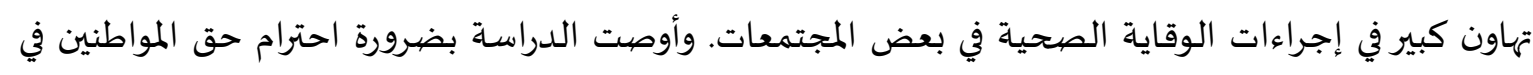

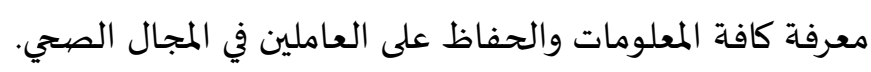
دراسة (الرقاص والعصيمي، 2020): هدفت الدراسة الى التعرف على درجة تطبيق الإجراءات الاحترازية في

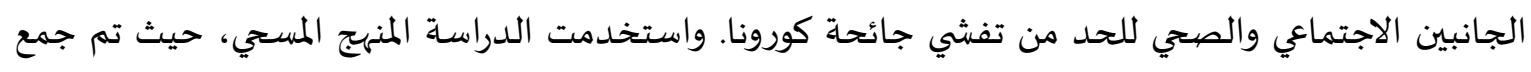

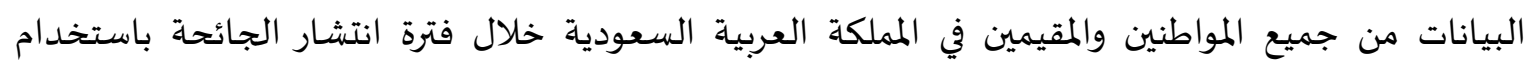


الاستبانة كأداة لجمع البيانات، وبينت نتائج الدراسة ارتفاع درجة استجابات أفراد عينة البحث حول الجانب

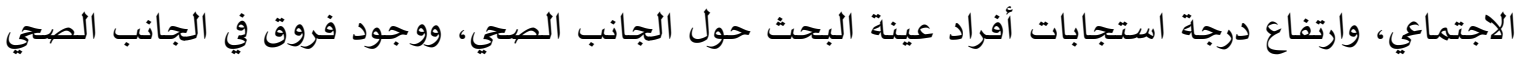

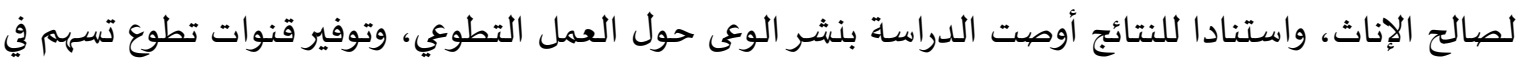
تكثيف الجهود حول الحد من أزمة كورونا. دراسة (Moeed, 2020): هدفت الدراسة إلى توفير منظور شمولي عن فيروس كورونا الجديد لمساعدة الباحثين

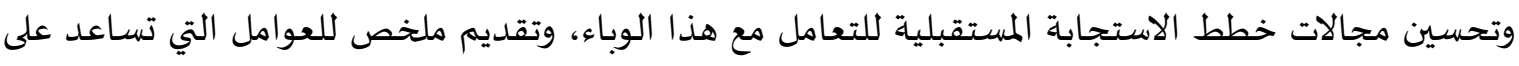

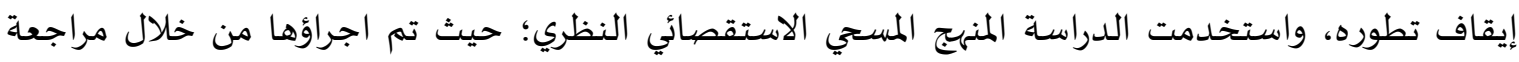

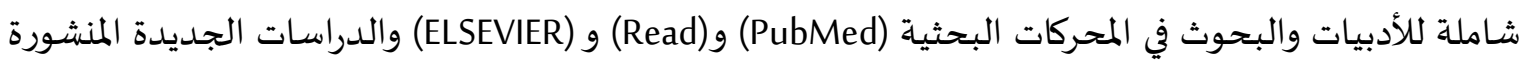

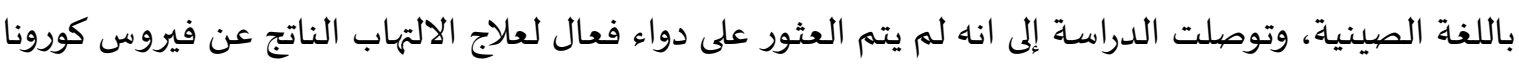

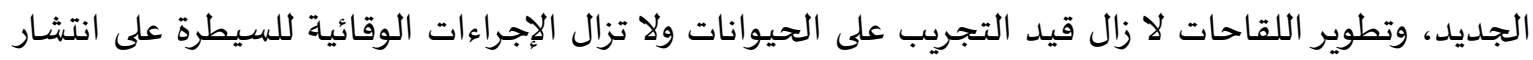

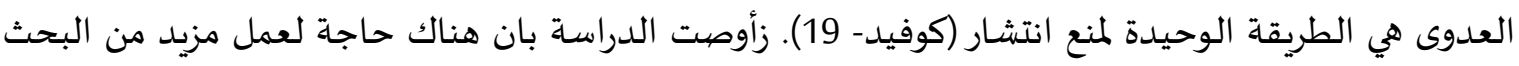
للسيطرة على فيروس كورونا (كوفيد- 19)، ولا تزال هناك حاجة إلى تطوير الاحتياطات وإجراءات الوقاية، خاصة لموظفي المستشفيات. دراسة (Ahmed, et al., 2020): هدفت الدراسة للتعرف على فيروس كورونا كوفيد - (SARS- CoV- 2)19) بناء

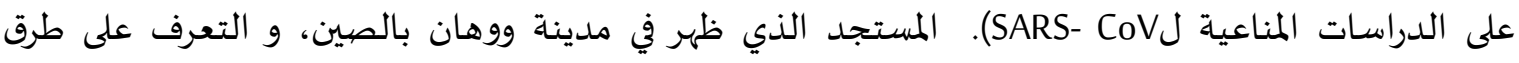

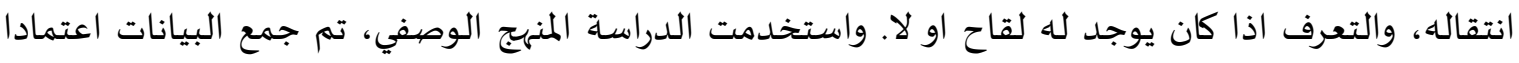

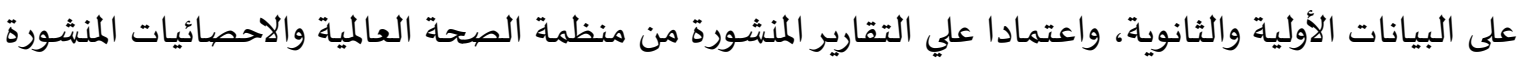

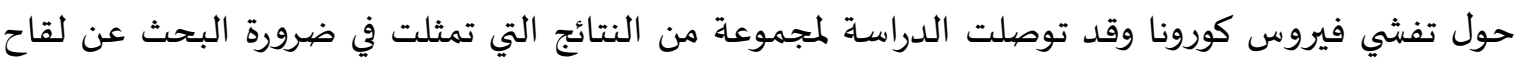

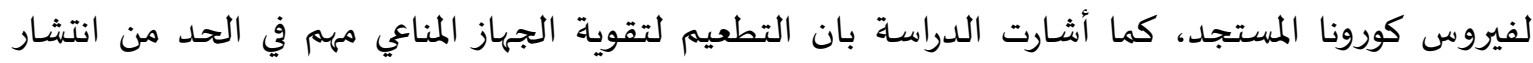
الفيروس. وقد أوصت الدراسة بضرورة اتباع وسائل الحماية والوقاية وكذلك الاهتمام بالتعقيم والنظافة. دراسة (Huang, et al., 2020): هدفت الدراسة للتعرف على فيروس كورونا المستجد، وكذلك التعرف على اعراض الإصابة بهذا الفيروس، وأيضا الكشف عن المصابين بهذا الفيروس، الفئ استخدمت الدراسة المنهج الوصفي

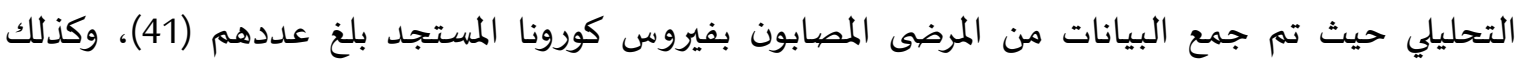

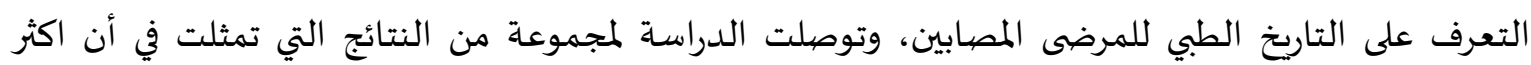

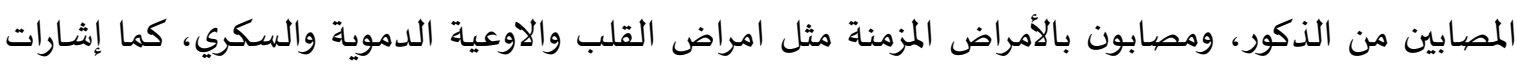

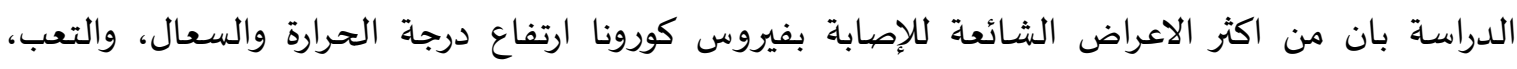

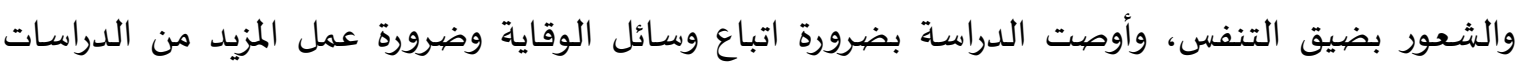

المتعلقة بالموضوع.

التعقيب على الدراسات السابقة: - السابع

يتضح من خلال الاطلاع على الدراسات السابقة انها بحثت للتعرف على فيروس كورونا وطرق انتشاره

وأعراضه وكيفية الكشف عن المصابين به وسبل مواجهته ودرجة تطبيق الإجراءات الاحترازية.

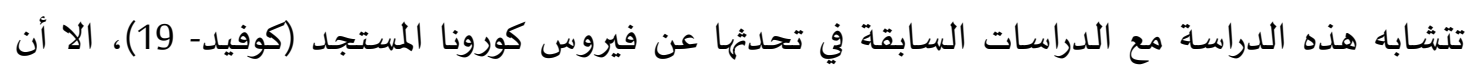

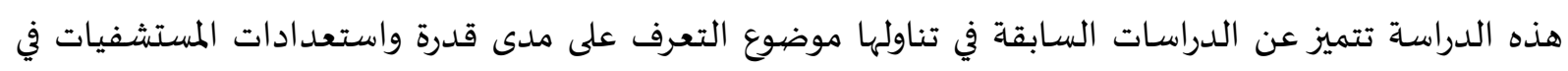
مديرية عمران لمواجهة ومنع تفشي مرض فيروس كورونا. 


\section{3- منهجية الدراسـة وإجراءاتها}

منهجية البحث: تم الاعتماد في هذه الدراسة على المنهج الوصفي التحليلي وتمت الدراسة مكانيا في مستشفيات

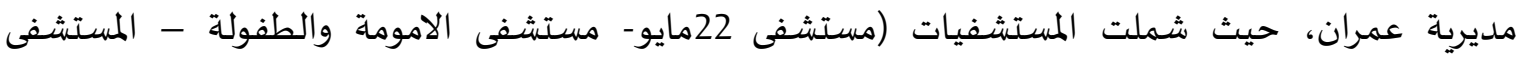
الاستشاري- مستشفى المأخذي - مستشفى الريان- مستشفى السلام).

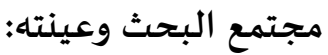

تكون مجتمع البحث من الفريق الصي والإداريين في مستشفيات مديرية عمران؛ الحكومية والخاصية، تم

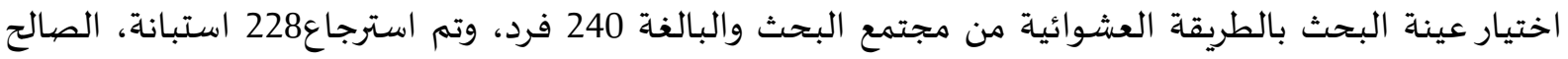

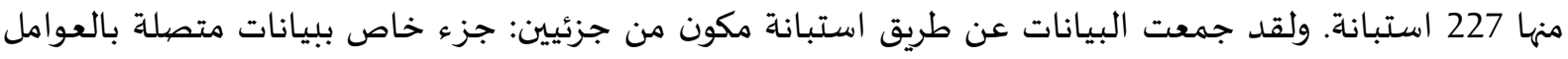

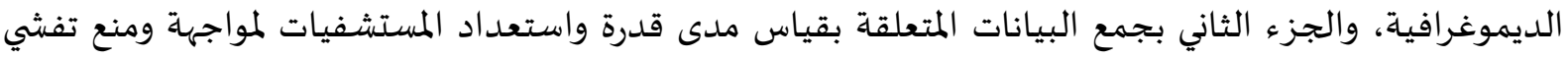
فيروس كورونا.

\section{الخصائص الديموغرافية:}

جدول رقم (1): الخصائص الديموغرافية لعينة البحث.

\begin{tabular}{|c|c|c|c|}
\hline النسبة المئوية & التكرار & فئات المتنغير & المتخير \\
\hline 13.7 & 31 & طبيب & \multirow{6}{*}{ التخصص } \\
\hline 32.2 & 73 & تمريض & \\
\hline 13.2 & 30 & صبيدلي & \\
\hline 30.0 & 68 & مخبري & \\
\hline 11.0 & 25 & اداري & \\
\hline 100.0 & 227 & المجموع & \\
\hline 3.5 & 8 & دكتوراه & \multirow{5}{*}{ المؤهل } \\
\hline 4.8 & 11 & ماجستير & \\
\hline 26.4 & 60 & بكالوريوس & \\
\hline 65.2 & 148 & دبلوم & \\
\hline 100.0 & 227 & المجموع & \\
\hline 59.9 & 136 & 1 -5سنوات & \multirow{4}{*}{ 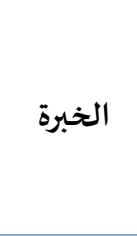 } \\
\hline 18.5 & 42 & 6 -10سنوات & \\
\hline 21.6 & 49 & اكثر من10 سنوات & \\
\hline 100.0 & 227 & المجموع & \\
\hline 49.3 & 112 & ذكر & \multirow{3}{*}{ الجنس } \\
\hline 50.7 & 115 & انثى انث & \\
\hline 100.0 & 227 & المجموع & \\
\hline 66.5 & 151 & 20 -30سنة & \multirow{5}{*}{ العمر } \\
\hline 25.6 & 58 & 31 -40 سنة & \\
\hline 5.7 & 13 & 50-41 41 & \\
\hline 2.2 & 5 & اكثر من 50 سنة & \\
\hline 100.0 & 227 & المجموع & \\
\hline 78.4 & 178 & حكومي & \\
\hline
\end{tabular}




\begin{tabular}{|c|c|c|c|}
\hline النسبة المئوية & التكرار & فئات المتخير & المتغير \\
\hline 21.6 & 49 & خاص & \multirow[t]{2}{*}{ وع المستشـى } \\
\hline 100.0 & 227 & المجموع & \\
\hline
\end{tabular}

يبين الجدول رقم (1) بعض الخصائص العامة لعينة البحث حيث يتضح أن أغلبية عينة الدراسة من فئة

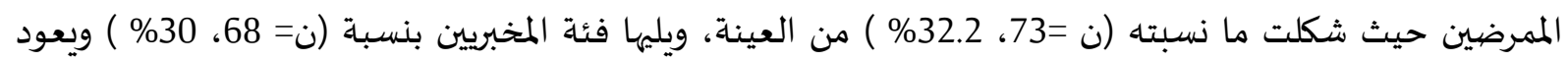

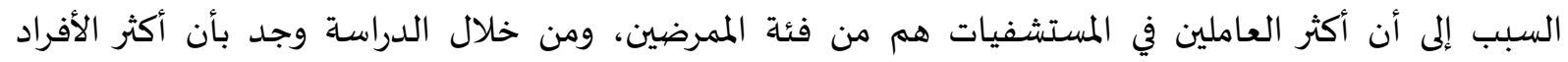

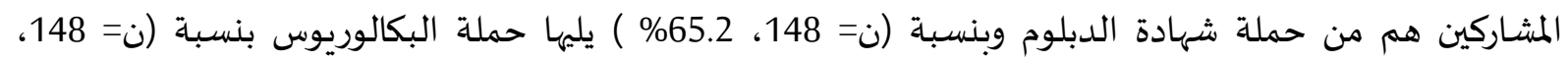

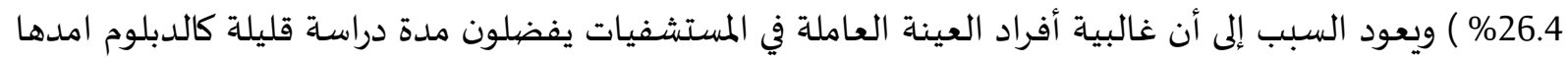

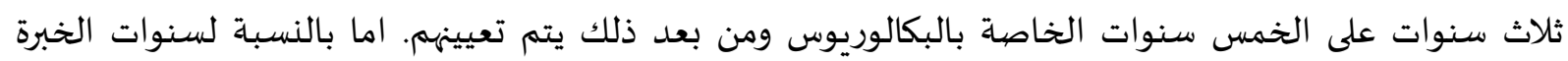

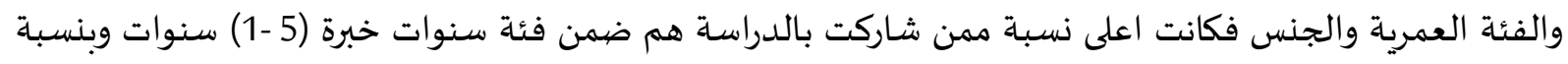

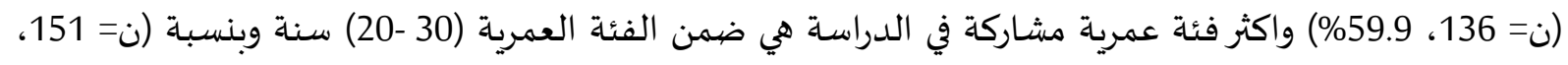

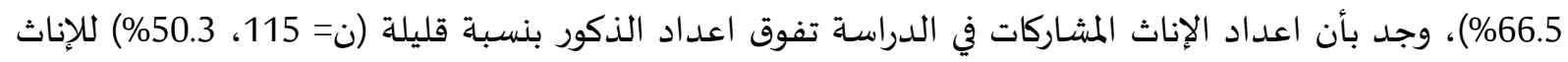
قياسا بالذكور (ن= 112، 49.7\%). وقد اتضح ايضا أن أغلب أفراد عينة البحث المشاركين هم من العاملين في المستشفيات الحكومية بنسبة (ن= 178، 78.4\%) كون العاملين بالمستشفيات الحكومية أكثر من المستشفيات

مصيداقية وثبات الأداة: تم التحقق من صدق الاداة من خلال عرضها على مجموعة من المتخصصين وقد

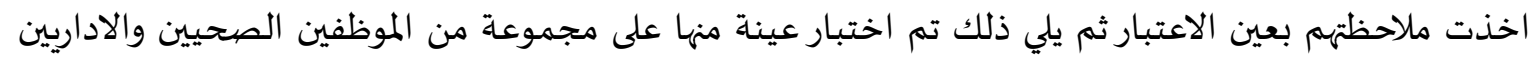
بالمستشفيات بغية اختبار الاتساق لمفردات الاستبانة. وتم اجراء اختبار الفا كرونباخ (Cronbach's Alpha)

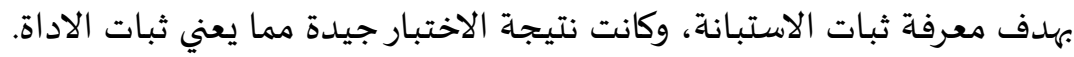

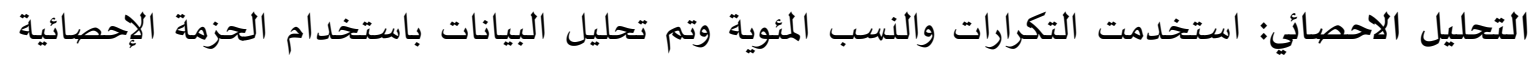
العلمية (SPSS) الإصدار السابع عشر. وتم استخدام اختبار كروسكال ويلز للرتب لمعرفة الفروق بين أفراد

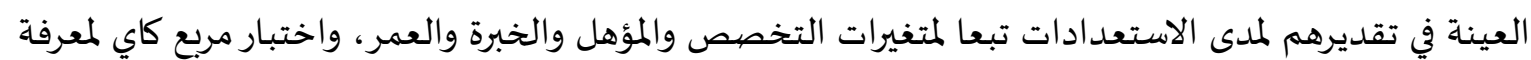

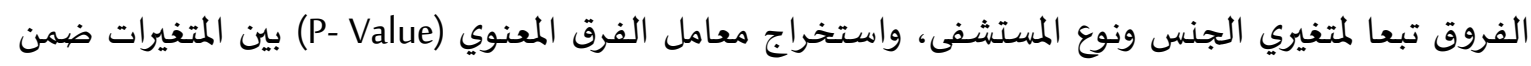
الدراسة الحالية واعتبرت ذات فرق معنوي عندما تكون قيمتها المعنوية اقل او تساوي (0.05).

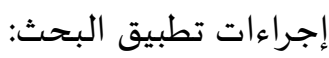

بعد انتهاء عملية التأكد من صددق وثبات الأداة وأصبحت في صهورتها الهنائية تم القيام بالاتي: 1. اخذ الموافقة لعمل البحث من عمادة كلية المجتمع الوطنية- م/عمران. 2. استخراج مذاكرات من الكلية للمستشفيات لتسهيل مهمة الباحثين. 3. بعد موافقة إدارات المستشفيات تم توزيع أداة البحث المتمثلة بالاستبانة على الفريق الصئي والاداريين في مئي المستشفيات. 4. في أيام التوزيع نفسها تم استرجاع الاستبانات وتفريغ البيانات وادخالها البرنامج الاحصائي SPSS لتحليلها. 4- عرض النتائج ومناقشتها في هذا القسم يتم الإجابة على أسئلة الدراسة والتحقق من فرضياتها، من خلال تحليل النتائج وعرضها: 
إجابة السؤال الأول: هل يوجد ما يكفي من معدات الفحص، والملابس الوقائية والأقنعة، وأجهزة التنفس

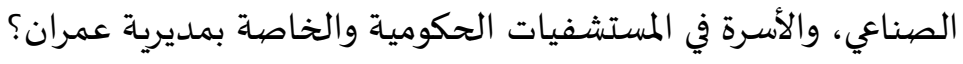

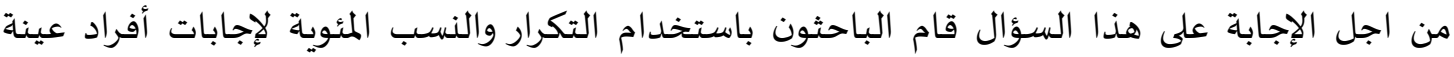

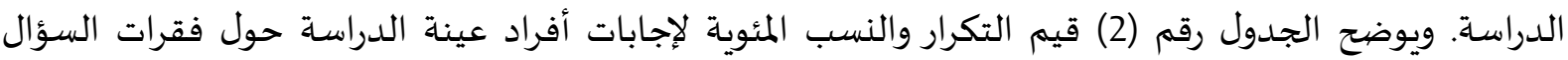

جدول رقم (2) قيم التكراروالنسب المئوية لإجابات أفراد عينة الدراسة حول فقرات سؤال البحث الأول:

\begin{tabular}{|c|c|c|c|c|}
\hline النسبة المئوية (\%) & التكرار & مستويات الإجابة & المتغيرات & ت \\
\hline 5.3 & 12 & نعم & \multirow{3}{*}{ هل يوجد لدى المستشفى أجهزة تشخيصية كجهاز PCR لتأكيد أو } & \multirow{3}{*}{1} \\
\hline 94.7 & 215 & لا & & \\
\hline 100.0 & 227 & المجموع & & \\
\hline 5.7 & 13 & 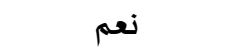 & \multirow{3}{*}{ هل تتوفر المحاليل الخاصة بجهاز PCR لفحص الاشخاص المتوقع } & \multirow{3}{*}{2} \\
\hline 94.3 & 214 & لا & & \\
\hline 100.0 & 227 & المجموع & & \\
\hline 25.6 & 58 & نعم & \multirow{3}{*}{ هل يوجد لدى المستشفى أجهزة استشعار حراري عن بعد لقياس } & \multirow{3}{*}{3} \\
\hline 74.4 & 169 & لا & & \\
\hline 100.0 & 227 & المجموع & & \\
\hline 16.3 & 37 & 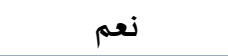 & \multirow{3}{*}{ يوجد في المستشفى عدد أسرة كافية في حال حدوث انتشار لمرض } & \multirow{3}{*}{4} \\
\hline 83.7 & 190 & ע & & \\
\hline 100.0 & 227 & المجموع & & \\
\hline 14.5 & 33 & نعم & \multirow{3}{*}{ هل يتوفر لدى المستشفى كميات كافية من أجهزة التنفس } & \multirow{3}{*}{5} \\
\hline 85.5 & 194 & ע & & \\
\hline 100.0 & 227 & المجموع & & \\
\hline 64.3 & 146 & نعم & \multirow{3}{*}{ هل تم تخصيص غرف أو أقسام عزل للحالات المشتبه بإصابتها } & \multirow{3}{*}{6} \\
\hline 35.7 & 81 & ע & & \\
\hline 100.0 & 227 & المجموع & & \\
\hline 54.6 & 124 & نعم - ن & \multirow{3}{*}{ وحدة العناية المركزة بالمستشفى على استعداد وجاهزية لاستقبال } & \multirow{3}{*}{7} \\
\hline 45.4 & 103 & لا & & \\
\hline 100.0 & 227 & المجموع & & \\
\hline 41.0 & 93 & نعم & \multirow{3}{*}{ يوجد في المستشفى أطباء متخصصي جهاز تنفسي ؟ } & \multirow{3}{*}{8} \\
\hline 59.0 & 134 & ע & & \\
\hline 100.0 & 227 & المجموع & & \\
\hline
\end{tabular}

يبين الجدول رقم (2) مجموعة من الأسئلة المتعلقة بسؤال البحث الأول، فقد أجاب غالبية أفراد العينة

(ن) لتأكيد أو نفي الحالات

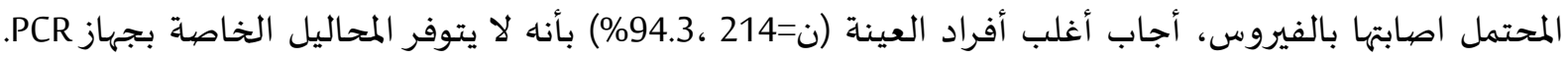
اما من ناحية توفر أجهزة الاستشعار الحراري (بالليزر) لقياس درجة حرارة المشتبه بإصابتهم بفيروس كورونا فقد المدابد

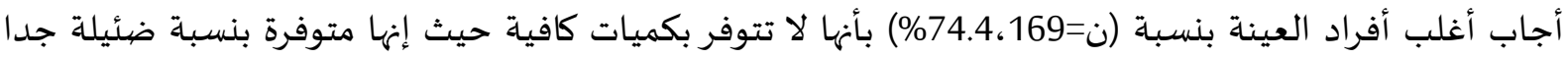

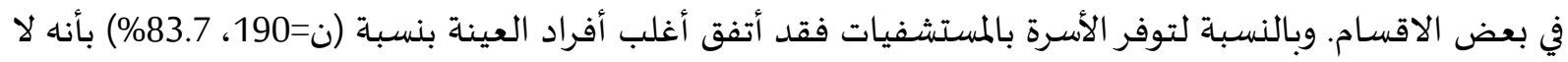

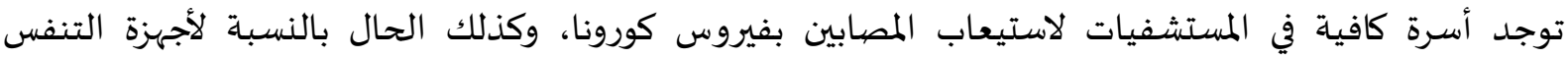


الصناعية فأنها غير كافية وقد أتفق أفراد العينة على ذلك بنسبة (ن=194، 85.5\%). تم سؤال أفراد العينة عن أذا تم تخصيص غرف وأقسام عزل للحالات المشتبه اصابتها بفيروس كورونا فقد أجاب الأكثر بنسبة (ن=146، 64.3\%) أنه بالفعل تم تخصيص أقسام للعزل. أجاب أكثر من نصف أفراد العينة (ن=124،54.6\%) بأن وحدة العناية المركزة على استعداد وجاهزية لاستقبال الحالات الحرجة المصابة بالفيروس ولعل ذلك يعود بأنه يوجد مشاركين في الدراسـة ليس عندهم علم بجاهزية العناية المركزة خصوصا المشاركين من ضمن فئة الصيادلة والمخبريين والإدارين. نسبة كبيرة من أفراد العينة (ن=134، 59\%) أجابوا بأنه لا يوجد أطباء متخصصي جهاز تنفسي بالمستشفيات وأن وجد ببعض المستشفيات فانة لا يزيد عن طبيب واحد متخصص جهاز تنفسي بالمستشفى. هإجابة السؤال الثاني: هل اتخذت إدارة المستشفيات بمديرية عمران الإجراءات الاحترازية والوقائية الكافية

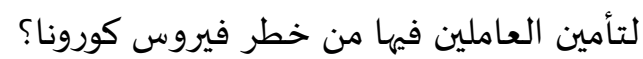
من اجل الإجابة على هذا التساؤل قام الباحثون باستخدام التكرار والنسب المئئوياة لإجابات أفراد عينة الدراسة. ويوضح الجدول رقم (3) قيم التكرار والنسب المئوية لإجابات أفراد عينة الدراسة حول فقرات السؤال الثاني: جدول رقم (3) قيم التكراروالنسب المئوية لإجابات أفراد عينة الدراسة حول فقرات سؤال البحث الثاني:
النسبة المئوية (\%)
التكرار
مستويات الإجابة
ا المتغيرات

\begin{tabular}{|c|c|c|c|c|}
\hline 38.3 & 87 & نعم & \multirow{3}{*}{ لتأمين الأطقم الطبية والمستى اتخذت كافة الإجراءات الاحترازية والوقائية } & \multirow{3}{*}{1} \\
\hline 61.6 & 140 & لا & & \\
\hline 100.0 & 227 & المجمموع & & \\
\hline 26.4 & 60 & نعم & \multirow{3}{*}{ يوجد بالمستشفى البدلات الخاصة للوقاية من فيروس كورونا؟ } & \multirow{3}{*}{2} \\
\hline 73.6 & 167 & لا & & \\
\hline 100.0 & 227 & المجموع & & \\
\hline 36.1 & 82 & نعم & \multirow{3}{*}{ هل يتم توزيع الكمامات بشكل يومي ومتكرر للعاملين في المستشفى من فيروض } & \multirow{3}{*}{3} \\
\hline 63.9 & 145 & ע & & \\
\hline 100.0 & 227 & المجموع & & \\
\hline 64.3 & 146 & نعم & \multirow{3}{*}{ خدمات التعقيم هل هي موجودة وكافية للمستشفى والعاملين فهيا } & \multirow{3}{*}{4} \\
\hline 35.7 & 81 & ע & & \\
\hline 100.0 & 227 & المجموع & & \\
\hline 43.2 & 98 & نعم & \multirow{3}{*}{ يتم الزام كل العاملين بالمستشفى بارتداء القفازات الواقية؟ } & \multirow{3}{*}{5} \\
\hline 56.8 & 229 & ل & & \\
\hline 100.0 & 227 & 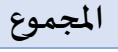 & & \\
\hline 17.6 & 40 & نعم & \multirow{3}{*}{ يتم الزام كل العاملين بالمستشفى بارتداء أغطية الرأس الواقية؟ } & \multirow{3}{*}{6} \\
\hline 82.4 & 187 & ע & & \\
\hline 100.0 & 227 & المجمموع & & \\
\hline
\end{tabular}

يبين الجدول رقم (3) مجموعة من الأسئلة المتعلقة بالسؤال الثاني، فقد أجابت عينة البحث بنسبة (ن=140، 61.7\%) بأن ادارات المستشفيات لم تتخذ كافة الإجراءات الاحترازية والوقائية لتأمين الأطقم الطبية والعاملين بالمستشفيات من خطر فيروس كورونا، حيث أجاب معظم أفراد العينة (ن=167، 73,6\%) أنه لم يتم توفير البدلات الخاصة للوقاية من فيروس كورونا بشكل كافي، وايضا أجاب أفراد العينة بنسبة (ن=145، 63.9\%) 
بأنه لا يتم توزيع الكمامات بشكل يومي ومتكرر للأطقم الطبية والعاملين بالمستشفيات، وبالنسبة لخدمات التعقيم

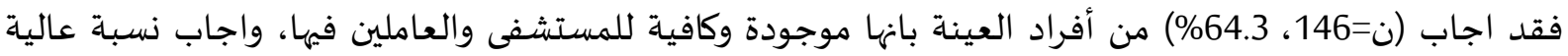
من أفراد العينة (ن=129، 56.8\%)،(ن=187، 82.4\%) بأنه لا يتم الزام العاملين بالمستشفيات بارتداء القفازات وأغطية الرأس الواقياة.

إجابة السؤال الثالث: هل دربت إدارة المستشفيات بمديرية عمران فرق عمل للتعامل مع المرضى المصابين أو

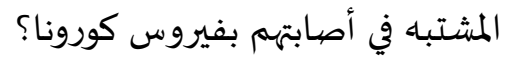

من اجل الإجابة على هذا التساؤل قام الباحثون باستخدام التكرار والنسب المئوية لإجابات أفراد عيداد عينة الدراسة. ويوضح الجدول رقم (4) قيم التكرار والنسب المئوية لإجابات أفراد عينة الدراسة حول فقرات السؤال

جدول رقم (4) قيم التكراروالنسب المئوية لإجابات أفراد عينة الدراسة حول فقرات سؤال البحث الثالث:

\begin{tabular}{|c|c|c|c|c|}
\hline النسبة المئوية & التكرار & مستوبات & المتغيرات & ت \\
\hline 63.4 & 144 & نعم & \multirow{3}{*}{ 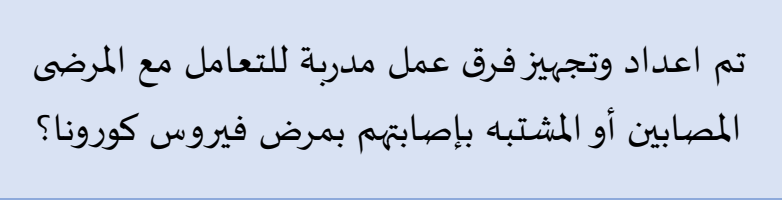 } & \multirow{3}{*}{1} \\
\hline 36.6 & 83 & V & & \\
\hline 100.0 & 227 & المجموع & & \\
\hline 36.6 & 83 & نعم & \multirow{3}{*}{ هل حضرت أي ورش عمل او دورات أو محاضرات تتعلق } & \multirow{3}{*}{2} \\
\hline 63.4 & 144 & 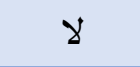 & & \\
\hline 100.0 & 227 & المجموع & & \\
\hline 61.2 & 139 & نعم & \multirow{3}{*}{ هل سبق لك أن تدربت على مكافحة والوقاية والحد من المن من من الامرض اضمدية؟ } & \multirow{3}{*}{3} \\
\hline 38.8 & 88 & $\gamma$ & & \\
\hline 100.0 & 227 & المجموع & & \\
\hline 65.6 & 149 & نعم & \multirow{3}{*}{ هل لديك خبرة سابقة في إدارة ومكافحة تفشي الامراض } & \multirow{3}{*}{4} \\
\hline 34.4 & 78 & $\gamma$ & & \\
\hline 100.0 & 227 & المجموع & & \\
\hline
\end{tabular}

يبين الجدول رقم (4) مجموعة من الأسئلة المتعلقة بسؤال البحث الثالث، بسؤال أفراد العينة هل تم

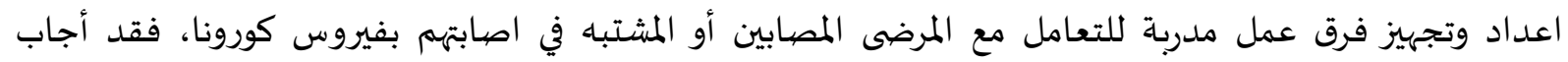

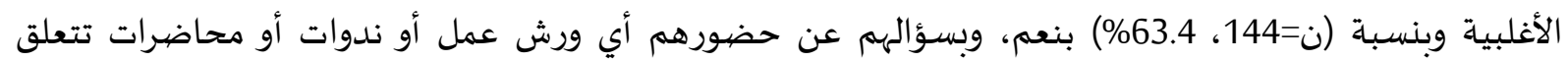

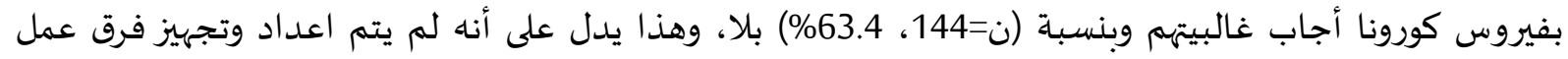

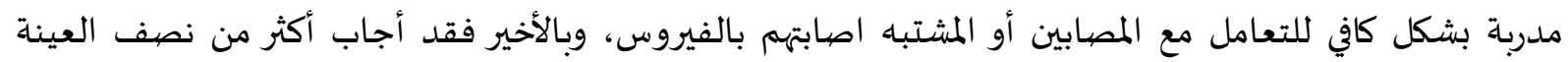

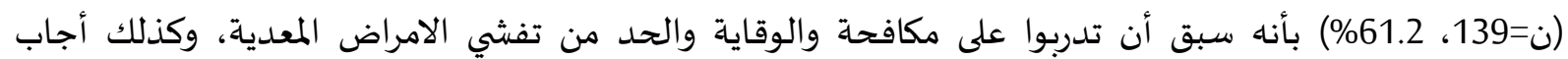
(ن=149،56.6\%) بأن لديهم خبرة سابقة في إدارة ومكافحة تفشي الامراض المعدية.

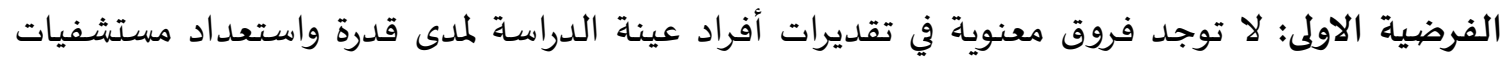

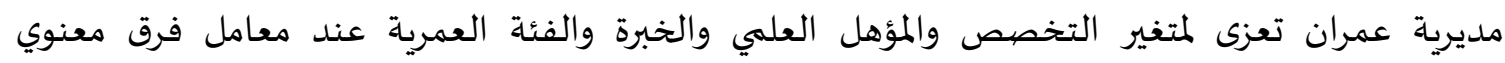
.(p.value=0.05) 
من اجل التحقق من صحة الفرضية قام الباحثون باستخدام اختبار كروسكال ويلز للرتب لمعرفة الفروق بين أفراد العينة. وكانت النتائج كما يلي:

جدول رقم (5): نتائج اختبار كروسكال ويلز للرتب لمعرفة الفروق بين أفراد العينة في تقديرهم لمدى قدرة واستعداد مستشفيات مديرية عمران لمواجهة ومنع تفشي مرض فيروس كورونا تبعاً لمتغيرات: التخصص

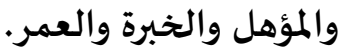

\begin{tabular}{|c|c|c|c|c|c|c|c|}
\hline \multirow{2}{*}{$\begin{array}{c}\text { الاحتمال } \\
\text { Sig. } \\
\text { (P.Value) }\end{array}$} & \multirow{2}{*}{$\begin{array}{c}\text { احصيائي } \\
\text { الاختبار } \\
\left(x^{2}\right)\end{array}$} & \multicolumn{5}{|c|}{ متوسط الرتب } & \multirow[b]{2}{*}{ المتغير } \\
\hline & & العينة 5 & العينة 4 & العينة 3 & العينة 2 & العينة 1 & \\
\hline & & إداري & مخبري & صيدلي & تمريض & طبيب & \multirow[b]{2}{*}{ التخصص } \\
\hline \multirow[t]{2}{*}{.058} & 9.11 & 104.22 & 119.01 & 135.75 & 102.76 & 116.32 & \\
\hline & & & دكتوراه & ماجستير & بكالوريوس & دبلوم & \multirow[b]{2}{*}{ المؤهل } \\
\hline \multirow[t]{2}{*}{.227} & 4.335 & & 94.69 & 103.91 & 105.10 & 119.40 & \\
\hline & & & & اكثر من10 & 6 -10سنوات & 1 -5سنوات & \multirow[b]{2}{*}{ الخبرة } \\
\hline \multirow[t]{2}{*}{.356} & 2.066 & & & 123.46 & 107.86 & 112.49 & \\
\hline & & & اكثر من 50 & 50- 41 & 31 -40سنة & 20 -30سنة & \multirow[b]{2}{*}{ العمر } \\
\hline .540 & 2.160 & & 81.00 & 106.27 & 114.98 & 115.38 & \\
\hline
\end{tabular}

يتبين لنا من خلال الجدول رقم (5) عدم وجود فروق معنوية عند معامل فرق معنوي (p.value=0.05) بين كل من التخصص والمؤهل والخبرة والفئة قياسا بمدى تقديرهم لقدرة واستعداد مستشفيات مديرية عمران لمواجهاة ومنع تفشي مرض فيروس كورونا. الفرضية الثانية: لا توجد فروق في تقديرات أفراد عينة الدراسة لمدى قدرة واستعداد مستشفيات مديرية عمران تعزى لمتغير الجنس ونوع المستشفى عند معامل فرق معنوي (p.value=0.05).

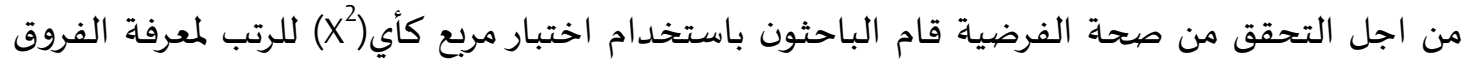

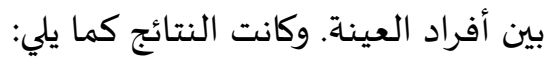
جدول رقم (6): نتائج اختبار مربع كأي(X2) للرتب لمعرفة الفروق بين أفراد العينة في تقديرهم لمدى قدرة

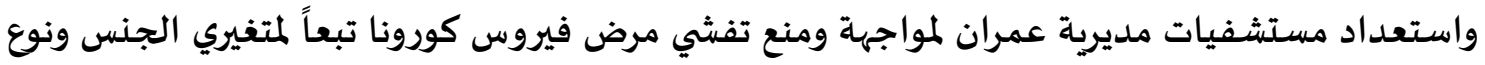
المستشفى.

\begin{tabular}{|c|c|c|c|}
\hline (P.Value) Sig. الاحتمال & احصيائي الاختبار (X2) & درجة الحرية & المتغير \\
\hline .435 & 1.663 & 2 & الجنس \\
\hline .466 & 1.528 & 2 & نوع المستشـفى \\
\hline
\end{tabular}

يتبين لنا من خلال الجدول رقم (6) عدم وجود فروق معنوية عند معامل فرق معنوي (p.value=0.05) بين

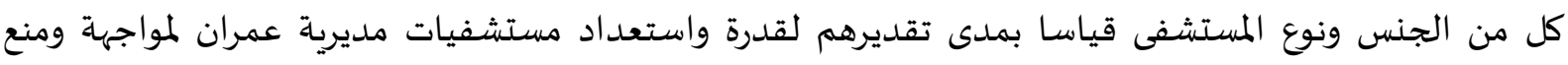
تفشي مرض فيروس كورونا. خلاصة نتائج الدراسة أظهرت نتائج الدراسـة: 
1. أن مستشفيات مديرية عمران والعاملين فيها ليسوا على استعداد كاف لمواجهة ومنع انتشار فيروس كورونا.

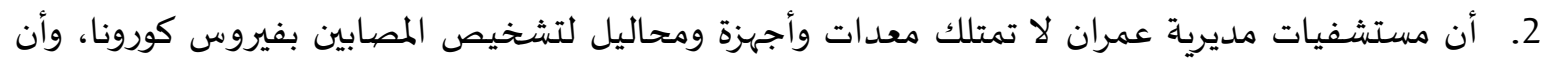
هناك نقص كبير جدا في الملابس الوقائية وأقنعة الوجه وأجهزة التنفس الصنهاعية وكذائلك أسرة

$$
\text { المستشفيات. }
$$

3. أن هناك نقصيا في الإجراءات الاحترازية والوقائية لتأمين العاملين في المستشفيات حيث لم يتم إلزام العاملين بارتداء القفازات وأغطية الرأس الواقية والاكتفاء بلبس الكمامات لمن أراد وتم الاكتفاء بزيادة إجراءات

$$
\text { التعقيم. }
$$

$$
\text { التوصيات والمقترحات }
$$

$$
\text { استنادا لنتائج الدراسة يوصي الباحثون ويقترحون الآتي: }
$$

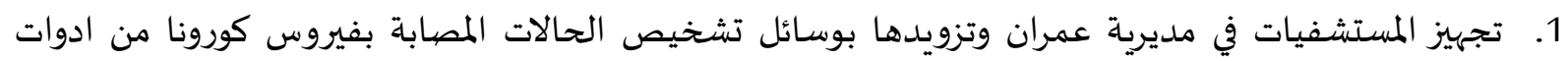

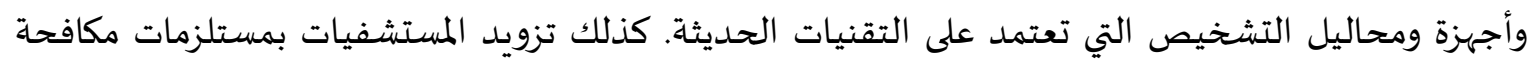

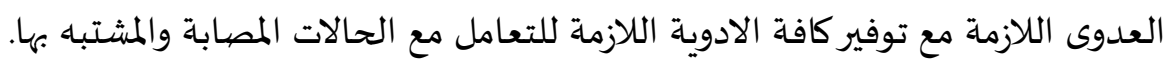

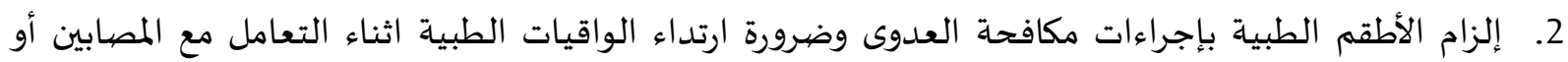

$$
\text { المشتبها في إصابتهم بفيروس كورونا. }
$$

3. وضع خطة تدربية تتضمن برامج تدرببية شاملة للعاملين بالمستشفيات لرفع كفاءتهم للتعامل مع هذه الجائحة. 4. إجراء دراسات مماثلة في بقية المديريات وفي إطار مقارن مع عواصهم المحافظات؛ داخدية داخل الجمهيهورية اليمنية. 5. إجراء دراسة على مستوى المستشفيات الكبرى، وتحديد الاحتياجات التشغيلية وسبل الحفاظ علئ عليها. 6. دراسة تتناول الكوادر البشرية المؤهلة ونسبتها إلى عدد السكان في كل مديرية ومحافظة.

\section{قائمة المراجع}

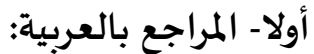

- الرقاص، غازي بندر؛ والعصيمي، بندر عبيد (2020). "درجة تطبيق الإجراءات الاحترازية الاجتماعية والصحية للحد من تفشي جائحة كورونا". المجلة العربية للنشر العلمي، العدد 22: 266 -289. السعودي، سعيد احمد سليمان (2020). "أزمة كورونا- سبل المواجهة والاستعداد- حالة دراسية قطاع غزة". المجلة العربية للنشر العلمي، العدد 67:19 -95.

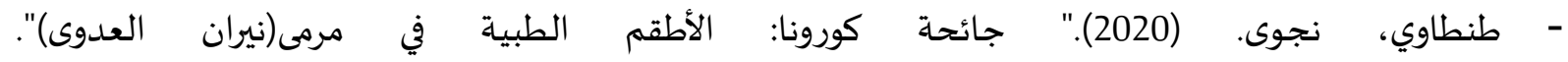
https://www.scientificamerican.com/arabic/articles/news/covid19- infection- medical-teams/ - العليوي، معاوية أنور. (2020). كورونا القادم من الشرق. ط1. منارة العله. دبي، الامارات. - كريم، محمد. (2020)." كيف اختبر كورونا كفاءة المستشفيات حول العالم؟". شبكة الجزيرة الإعلامية: https://www.google.com/amp/s/www.aljazeera.net/amp/blogs/2020/3/18/\%25D9\%2583\%25D9 -\%258A\%25D9\%2581 http:/www.emero.who.int/ar/health- منظمة الصحة العالمية(2020)، فيروس كورونا Covid- 19 topics/corona- virus/about- covid-19.html 
- Ahmed, Syed Faraz. Et al, (2020). "Preliminary identification of potential vaccine targets for the COVID- 19 Coronavirus (SARS- CoV- 2) based on SARS- CoV immunological studies". MDPI, 12(3): 254

- Doremalen, Neeltje Van. et al, (2020) “Aerosol and Surface Stability of SARS- CoV- 2 as compared with SARS- CoV-1,"The New England Journal of Medicine, 382(16), 1564- 1567

- Huang, MD. et al,(2020). "Clinical features of patients infected with 2019 novel coronavirus in Wuhan, China". The lancet journals, 395: 497- 506

- IFRC, UNICEF \& WHO, (2020), Social stigma associated with COVID- 19, https://www.epiwin.com/sites/epiwin/files/content/attachments/2020- 02- 24/COVID19\%20Guide\%20240220201.pdf. Accessed 2020 March 3.

- Kaamil Ahmed, (2020) "World's most vulnerable in 'third wave' for covid- 19 support, experts warn," The Guardian.https://www.theguardian.com/global- development/2020/mar/20/worlds- mostvulnerable- in- third- wave- for- covid-19- support- warn- experts.

- Marc Lipsitch, (2020)“Seasonality of SARS- CoV- 2: Will COVID- 19 go away on its own in warmer weather?" Center for Communicable Disease Dynamics, Harvard T.H. Chan School of Public Health, https://ccdd.hsph.harvard.edu/will- covid- 19- go- away- on- its- own- in- warmer- weather/. Accessed 2020 March 3.

- Moeed, Yahya Ali Gaber. et al, (2020)." Research progress of new coronavirus (Covid- 19):Theoretical study" , AJSRP, 4(1): 140- 159

- UN Office for the Coordination of Humanitarian Affairs, (2019) "2019 Humanitarian Response Plan," https://yemen .un.org/sites/default/files/2019- 08/2019_Yemen_HRP_V21.pdf. Accessed 2020 March 3.

- World Health Organization,(2019) "Coronavirus disease (COVID- 19) advice for the public: Myth buster" https://www.who.int/emergencies/diseases/novel- coronavirus- 2019/advice- forpublic/myth- busters. Accessed 2020 March 3. 